\title{
Returning the Physician Assistant Profession to its Roots, Could Ease the Tension and Reduce Animosity
}

\section{Ayoade $\mathbf{S}^{*}$}

Department of Physiology, University of Ibadan, Oyo State, Nigeria

\section{Commentary}

Going through any physician assistant forum on the internet, one often hears many (not all) American PAs (Physician Assistants) complaining about being underappreciated and mistreated by doctors and patients alike. They generally bemoan their lot; and some are now calling for the profession's name to be changed from Physician Assistant to Physician Associate (like it is called in the UK). It appears that $70 \%$ of American PAs believe they have received a rather raw deal [1].

Personally I think the cause of this problem lies in the lengthy duration of PA training in America. In the USA today it takes 6 years of post secondary education to become a PA. In other countries (except for Canada, Australia and the UK) the equivalent of PAs are trained for at most 4 years (post secondary). I can understand why after 6 years of training a PA would like to receive the respect of someone that trained just 2 years extra. I can perfectly understand why a PA who trained for 6 years wouldn't like to take orders from a doctor from a commonwealth country or the UK where it takes 6 years to become a doctor [2].

Sometimes the solution to a problem lies in going back to its roots. When the PA program was started in the US in 1965 the training took only 2 years and the graduates were issued a simple certificate, not even a degree. Today, most PAs get Masters degrees [3-5].

Those first generation PA students (there were just four of them, three of whom graduated) were former USA Army/Navy medics/ corpsmen and already had paramedic level training. This previous training had taken them a maximum of 2 years. Today paramedics and USA Army and Navy corpsmen/medics still qualify within 6 months to 2 years. However for PAs the training time has more than doubled. I think this is the reason for the bad blood between PAs and doctors in the USA. It appears PAs feel the respect/pay they currently receive is not commensurate to the years they spent in training- and who can blame them? If PA training took a maximum of 4 years (post high school diploma) there would be far fewer angry PAs on the internet bemoaning their lot. In countries where PA training is many years shorter than doctor training there are far fewer doctor/PA clashes [6-8.

It shouldn't take more than 4 years to become a PA. As a neutral outsider and non American this is my sincere and humble view (Table 1).

Meanwhile Nigeria, a less developed country urgently needs physician assistants. Decades ago, the PA profession was introduced to Ghana, a country of 28 million. Yet Nigeria, a nation of 180 million people and a serious shortage of medical supplies, infrastructure and personnel does not have the physician assistant profession! I strongly urge for its creation.

In a letter dated September 24, 1964, Eugene Stead, Duke University chair of medicine department stated the following about developing the PA program:

The Department of Medicine of Duke University Medical Center is establishing a program to create a new position in the health field. We have chosen to call these individuals 'physician-assistant.' We believe there is a need for males to be committed to the health field to fill a

\begin{tabular}{|c|c|c|}
\hline Country & Designation & $\begin{array}{c}\text { Duration of training } \\
\text { (post-secondary) }\end{array}$ \\
\hline USA & Physician Assistant & 6 years \\
\hline $\begin{array}{c}\text { Russia and some } \\
\text { eastern European } \\
\text { countries }\end{array}$ & Feldsher & Maximum of 4 years \\
\hline Kenya & Clinical Officer & 3 to 4 years \\
\hline China & Assistant Doctor & 3 years \\
\hline Zambia & Medical Licentiate & 3 years \\
\hline South Africa & Clinical Associate & 3 years \\
\hline Uganda & $\begin{array}{c}\text { Bachelor of Clinical Medicine } \\
\text { and Community Health }\end{array}$ & 3 years \\
\hline India & Physician Assistant & 4 years \\
\hline Banzania & $\begin{array}{c}\text { Assistant Medical officer } \\
\text { and Surgery }\end{array}$ & 3 to 4 years \\
\hline Ghana & Physician Assistant & 4 years \\
\hline
\end{tabular}

Table 1: A comparison of the duration of physician assitant training in some countries.

gap between the physician and the nurse. This gap cannot be filled by additional training for nurses because nurses are already in very short supply $[9,10]$.

These individuals will become skilled in many areas of the medical profession, such as general patient care, intravenous therapy, cardiac resuscitation, respiratory care, catheterization of the bladder, lumbar puncture, paracentesis, gastric and intestinal intubation-to name just a few. They will be capable of extending the arms and brains of the physician, so that he can care for more people. They will work under physician supervision in the home, the clinic, the hospital, and in specialized medical care units.

Can anyone honestly argue it takes six years to teach the above? The physician assistant profession has strayed wildly from the dream of its founding fathers!

\section{References}

1. www.kevinmd.com/blog/2011/04/physician-assistant-writes-doctors-america html

2. https://www.physicianassistantforum.com/topic/12248-do-not-become-a-pa/

3. paprogram.yale.edu/profession/history_profession.aspx.

*Corresponding author: Mr. Seun Ayoade, BSc (Hons) Department of Physiology University of Ibadan, P.O. Box 22325, Oyo State, Nigeria, Tel: +2348060221764; E-mail: seunoodua@yahoo.com

Received September 08, 2017; Accepted September 27, 2017; Published September 30, 2017

Citation: Ayoade S (2017) Returning the Physician Assistant Profession to its Roots, Could Ease the Tension and Reduce Animosity. J Mol Genet Med 11: 279 doi:10.4172/1747-0862.1000279

Copyright: (C) 2017 Ayoade S. This is an open-access article distributed under the terms of the Creative Commons Attribution License, which permits unrestricted use, distribution, and reproduction in any medium, provided the original author and source are credited 
Citation: Ayoade S (2017) Returning the Physician Assistant Profession to its Roots, Could Ease the Tension and Reduce Animosity. J Mol Genet Med 11: 279 doi:10.4172/1747-0862.1000279

Page 2 of 2

4. Cobb ET, Adjase MD, Dip MPH (2014) The physician assistant profession in Ghana. Health Systems Management.

5. journa/s.Iww.com/jaapa/Fulltext/2015/04000/Physician_assistants_in Ghana.1.aspx by ET Adjase - 2015

6. https://cfm.duke.edu/...physician-assistant-program/.../duke-physicianassistant-progra.

7. Kossoy E, Ohry A (1992) The Feldsher: Medical, sociological and historical aspects of practitioners of medicine with below university level education, the Magnes Press, Hebrew University, Jerusalem.
8. Floyd K, Hutubessy R, Samyshkin Y, Korobitsyn A, Fedorin I, et al. (2006) Health-systems efficiency in the Russian federation: Tuberculosis control. Bul World Health Organ 84: 1-80.

9. Wilson A, Thangaratinam S, Khan K, MaCarthur C, Coomarasamy A (2011) A comparison of clinical officers with medical doctors on outcomes of caesarean section in the developing world: meta-analysis of controlled studies. BMJ 342 d2600.

10. Ferrinho P, Siziya S, Goma F, Dussault G (2011) The human resource for health situation in Zambia: deficit and maldistribution. Hum Resour Health 9: 30. 